\title{
FORMALISASI SISTEM PEMERINTAHAN ISLAM (STUDI TENTANG IMPLEMENTASI KEBIJAKAN PEMERINTAH TERHADAP PERDA BACA TULIS AL-QURAN DI KOTA MAKASSAR)
}

\author{
FORMALIZATION OF ISLAMIC GOVERNMENT SYSTEM \\ (STUDY ON THE IMPLEMENTATION OF THE GOVERNMENT \\ PERDA READ WRITE IN THE CITY OF AL-QURAN MAKASSAR)
}

\author{
M. Anwar Basir ${ }^{1}$, Jaelan Usman ${ }^{2}$, Abd. Rahman ${ }^{3}$ \\ ${ }^{1}$ Program Studi Ilmu Pemerintahan Fakultas Ilmu Sosial Dan Ilmu Politik \\ ${ }^{2}$ Program Studi Ilmu Pemerintahan Fakultas Ilmu Sosial Dan Ilmu Politik \\ ${ }^{3}$ Program Studi Ilmu Administrasi Negara Fakultas Ilmu Sosial Dan Ilmu Politik \\ Universitas Muhammadiyah Makassar \\ Jl. Sultan Alaudin No. 259 Makassar 90221 \\ Tlp. 0411-866972 ext. 107. Fax. 0411-8655888
}

\begin{abstract}
Perda Literacy Al-Quran (BCTA) which passed in 27 April 2012, but actually this regulation has long proclaimed the new year, but this can be realized and in Perda. Researchers are encouraged to try to describe and explain the Islamic Government Study On Implementation Of Government Policy Regulation Literacy Al-Quran In Makassar. Type of study is a survey approach, using interviews and questionnaires as material to reveal the facts and data necessary research to support the discussion of research. Survey and interview approach is an approach in making the news and the fact that these events are found relative, the distribution for further research. surveys and interviews are also used to investigate the implementation of government policies in achieving the objectives for the implementation of Regulation Literacy Al-Quran, study uses informants. This study uses data analysis techniques derived from the results of this study will be analyzed descriptively the result of an interview with the informants and respondents will also be supported with quantitative data in the form frekuensi.Hasil tabulation showed that people have taken enthusiastically to the government's policy the enforcement of laws Literacy Quran could bring a lot more people know the Koran and fluent in reading the Al-Quran for the betterment of life towards a better society, Till hopes ideals of the nation can be achieved as stated in the introduction of legislation (nation intellectual life and participate in the establishment of world order bedasarkan lasting peace and social justice for all Indonesian people), the next generation will be a major Insan literacy understand the Quran for the continued life of the nation and the state can be achieved.
\end{abstract}

Keywords: Implementation, BCTA Policy. 


\section{ABSTRAK}

PERDA Baca Tulis Al-Quran (BCTA) yang disahkan pada bulan 27 April 2012, tetapi sebenarnuya perda ini sudah lama dicanangkan namun baru tahun ini dapat terealisasikan dan di perda. peneliti terdorong untuk mencoba menggambarkan dan menjelaskan Pemerintahan Islam Study Tentang Implementasi Kebijakan Pemerintah Terhadap Perda Baca Tulis Al-Quran Di Kota Makassar. Jenis Penelitian ini merupakan pendekatan survey, wawancara dan menggunakan kuesioner sebagai bahan untuk mengungkap data dan fakta penelitian yang diperlukan untuk mendukung pembahasan penelitian. Pendekatan survey dan wawancara merupakan suatu pendekatan dalam pengambilan berita dan fakta sehingga ditemukan kejadian-kejadian relatif, distribusi untuk penelitian lebih lanjut. survey dan wawancara juga digunakan untuk menyelidiki tentang Implementasi Kebijakan Pemerintah dalam mencapai tujuan demi terlaksananya Perda Baca Tulis Al-Quran, Penelitian ini menggunakan informan. Penelitian ini menggunakan teknik analisa Data yang diperoleh dari hasil penelitian ini akan dianalisa secara deskriptif yakni hasil dari wawacara dengan informan dan responden yang juga akan didukung dengan data-data kuantitatif dalam bentuk tabulasi frekuensi.

Hasil penelitian menunjukkan bahwa masyarakat memiliki antusias terhadap kebijakan yang diambil pemerintah dalam pemberlakuan Perda Baca Tulis Al-Quran yang bisa membawa masyarakat jauh lebih mengenal Al-Quran dan fasih dalam membaca Al-Quran demi perbaikan hidup masyarakat kearah yang lebih baik, Hingga harapan cita-cita bangsa dapat tercapai sebagaimana yang tertuang dalam pembukaan perundang-undangan (mencerdaskan kehidupan bangsa dan ikut melaksanakan ketertiban dunia yang bedasarkan perdamaian abadi dan keadilan sosial bagi seluruh Rakyat Indonesia), generasi penerus akan menjadi Insan yang utama yang paham baca tulis Al-Quran demi kelangsungan kehidupan bangsa dan negara dapat tercapai.

Kata kunci: Implementasi, Kebijakan BCTA (Baca tulis Al-Quran)

\section{A. PENDAHULUAN}

Sistem pemerintahan Islam adalah sistem pemerintahan yang menggunakan Al-Quran dan Sunnah sebagai rujukan dalam semua aspek hidup, seperti dasar undang-undang, mahkamah perundangan, pendidikan, dakwah dan perhubungan, kebajikan, ekonomi, sosial, kebudayaan dan penulisan, kesehatan, pertanian, sains dan teknologi, penerangan dan peternakan. Dasar negaranya adalah Al Quran dan Sunnah. Para pemimpin dan pegawaipegawai pemerintahannya adalah orang-orang baik, bertanggung jawab, jujur, amanah, adil, faham Islam, berakhlak mulia dan bertakwa. Dasar pelajaran dan pendidikannya ialah dasar pendidikan Rasulullah, yang dapat melahirkan orang dunia dan orang Akhirat, berwatak abid dan singa, bertugas sebagai hamba dan khalifah Allah (Mohammad Arshad, Sistem Pemerintahan Islam Suatu Sinar Keadilan" 2010).
Politik dan hukum ketatanegaraan merupakan suatu persoalan yang sangat penting sebagai suatu sarana untuk mengatur dan menjalankan proses pemerintahan. Namun mispresepsi atau pun banyak perbedaan pendapat mengenai persoalan tersebut tidak dapat dipersalahkan begitu saja. Karena pembahasan atau kajian tentang masalah ini khususnya hukum tata Negara Islam masih sangat minim dilakukan. Dalam hal ini pun biasanya hanya dilakukan oleh kalangan tertentu dan kurang adanya sosialisasi sehingga umat muslim secara umum masih kurang atau belum mengetahui dan memahaminya.

Sistem ekonominya bersih dan adil. Suci dari riba, monopoli, penindasan, penipuan dan hal haram lainnya. Pembagiannya adil menurut keperluan untuk kemudahan, kewajiban, kedudukan dan bidang seseorang. Sistem sosialnya bersih dari kemungkaran dan maksiat terang-terangan. Setiap orang dihormati hak asasinya serta diberi peluang untuk 
melaksanakan hak-hak asasi masing-masing sesuai dengan bakat dan kebolehannya. Sistem ketentaraan berjalan atas disiplin Islam. Kebudayaan dan adat-istiadat dibenarkan berbagai asalkan semuanya tidak bertentangan dengan Islam.

Belakangan ini marak diperbincangkan di Dewan Perwakilan Rakyat mengenai pemberlakuan PERDA Baca Tulis Al-Quran (BCTA) yang disahkan pada bulan 27 April 2012, tetapi sebenarnya Perda ini sudah lama dicanangkan namun baru tahun ini dapat terealisasikan dan di perdakan.

Sebenarnya perda ini tidak asing lagi karena daerah/kota lain Pemkot Bogor, Pemkab Pulau Bintang, Pemkab Madura, Pemkab Gowa, Pemkab Takalar dan Pemkab Bulukumba telah membuat aturan tersebut sejak lama namun baru tahun ini dapat diberlakukan di Kota Makassar.

Setelah diberlakukan perda sejak di sahkannya, kami berniat untuk melakukan penelitian mengenai sejauh mana pemerintah berperan aktif dalam pelaksanaan perda BCTA dan Kementerian Agama serta salah satu Organisasi Kepemudaan yang sejak lama telah melaksanakan evaluasi terhadap bacaan AlQuran anak santri yang nantinya di wisuda dengan melihat dari sudut ini kami melihat perlunya diadakan penjajakan/penulusuran terhadap perda BCTA tersebut.

Penulis sangat terpanggil untuk melakukan penelitian terhadap persoalan diatas, melalui penelitian di harapkan hasilnya dapat memberikan kontribusi bagi sulawesi Selatan terkhusus di kota Makassar.

\section{B. KERANGKA TEORITIS}

Implementasi Bermuara pada aktivitas, aksi, tindakan atau adanya mekanisme suatu sistem. Implementasi bukan sekedar aktivitas, tetapi suatu kegiatan yang terencana dan untuk mencapai tujuan kegiatan, (Usman, 2002:70), Perluasan aktifitas yang saling menyesuaikan proses interaksi antara tujuan dan tindakan untuk mencapainya serta memerlukan jaringan pelaksana, birokrasi yang efektif, (Setiawan, 2004:39), Suatu proses untuk melaksanakan kebijakan menjadi tindakan kebijakan dari politik kedalam admistrasi. Pengembangan kebijakan dalam rangka penyempurnaan suatu program, (Harsono, 2002:67), Kebijakan adalah suatu tindakan yang mengarah pada tujuan yang diusulkan oleh seseorang, kelompok atau pemerintah dalam lingkungan tertentu sehubungan dengan adanya hambatanhambatan tertentu sambil mencari peluang untuk mencapai tujuan/mewujudkan sasaran yang diinginkan (dalam Tangkilisan, 2003:12), kebijakan Pemerintah, Kebijaksanaan memerlukan pertimbangan-pertimbangan yang lebih jauh lagi (lebih menekankan kepada kearifan seseorang), sedangkan kebijakan mencangkup aturan-aturan yang ada didalamnya sehingga Policy lebih tepat diartikan sebagai kebijakan, sedangkan kebijaksanaan merupakan pengertian dari kata Wisdom (Islamy, 1997:5), kebijakan pemerintah suatu upaya untuk mencapai tujuan-tujuan tertentu dengan sarana-sarana tertentu dan dalam urutan waktu tertentu (Bambang Sunggono 1994 : 137).

Pemerintah Demokrasi adalah suatu bentuk pemerintahan politik yang kekuasaan pemerintahannya berasal dari rakyat, baik secara langsung (demokrasi langsung) atau melalui perwakilan (demokrasi perwakilan). Istilah ini berasal dari bahasa Yunani (demokratía) "kekuasaan rakyat", yang dibentuk dari kata (demos) "rakyat" dan (Kratos) "kekuasaan", merujuk pada sistem politik yang muncul pada pertengahan abad ke-5 dan ke-4 SM di negara kota Yunani Kuno, khususnya Athena, menyusul revolusi rakyat pada tahun 508 SM.

Istilah demokrasi diperkenalkan pertama kali oleh Aristoteles sebagai suatu bentuk pemerintahan, yaitu pemerintahan yang menggariskan bahwa kekuasaan berada di tangan orang banyak (rakyat). Abraham Lincoln dalam pidato Gettys burgnya mendefinisikan demokrasi sebagai "pemerintahan dari rakyat, oleh rakyat, dan untuk rakyat". Hal ini berarti kekuasaan tertinggi dalam sistem demokrasi ada di tangan rakyat dan rakyat mempunyai hak, kesempatan dan suara yang sama di dalam mengatur kebijakan pemerintahan. Melalui demokrasi, keputusan yang diambil berdasarkan suara terbanyak. 
Diskursus demokrasi di Indonesia tak dapat dipungkiri, telah melewati perjalanan sejarah yang demikian panjangnya. Berbagai ide dan cara telah coba dilontarkan dan dilakukan guna memenuhi tuntutan demokratisasi di negara kepulauan ini. Usaha untuk memenuhi tuntutan mewujudkan pemerintahan yang demokratis tersebut misalnya dapat dilihat dari hadirnya rumusan model demokrasi Indonesia di dua zaman pemerintahan Indonesia, yakni Orde Lama dan Orde Baru. Di zaman pemerintahan Soekarno dikenal yang dinamakan model Demokrasi Terpimpin, lalu berikutnya di zaman pemerintahan Soeharto model demokrasi yang dijalankan adalah model Demokrasi Pancasila. Namun, alih-alih mempunyai suatu pemerintahan yang demokratis, model demokrasi yang ditawarkan di dua rezim awal pemerintahan Indonesia tersebut malah memunculkan pemerintahan yang otoritarian, yang membelenggu kebebasan politik warganya.

Akibat dari hal tersebut, representasi keberagaman kesadaran politik masyarakat ke dunia publik pun menjadi minim. Demokrasi yang terjadi di Indonesia kini, akhirnya hanya bisa dilihat sebagai demokrasi elitis, dimana kekuasaan terletak pada sirkulasi para elit. Rakyat hanya sebagai pendukung, untuk memilih siapa dari kelompok elit yang sebaiknya memerintah masyarakat.

Sistem pemerintahan Islam Study tentang Implementasi kebijakan pemerintah terhadap perda Baca tulis Al-Quran di Kota Makassar. Dengan berlakunya PERDA Baca Tulis AlQuran ini terkadang banyak hal yang masih harus dienahi sebagai aturan baru (PERDA baru) banyak tantangan atau komentar dari berbagai pihak dan lapisan masyarakat baik itu dalam ummat muslim itu sendiri maupun dari ummat non-muslim, dalam pemberlakuan perda ini pemerintah tentunya harus jeli melihat situasi atau kondisi yang berkembang dalam artian pemerintah harus sering melakukan evaluasi dan pengawasan terhadap perda tersebut, demi kesempurnaan perda tersebut.

\section{METODE PENELITIAN}

Penelitian ini dilaksanakan di Kota Makassar, dengan pertimbangan bahwa Kota Makassar merupakan Ibu kota Propinsi Sulawesi Selatan dan juga merupakan kota terbesar di Kawasan Indonesia Timur. Selain itu, juga karena pertimbangan efisiensi dan efektifitas penggunaan biaya dan waktu dalam pelaksanaan penelitian serta pemerintah Makassar baru-baru ini megesahkan perda Baca Tulis Al-Quran. Penelitian akan dilaksanakan kurang lebih 2 (dua) bulan dari bulan September - November 2012.

Dasar penelitian yang digunakan adalah survey yaitu metode yang mengumpulkan dan menganalisis data dan informasi dari sejumlah responden dan informan yang dianggap dapat memberikan informasi yang berhubungan dengan penelitian ini. Tipe penelitian yang digunakan adalah tipe penelitian deskriptif suatu penelitian yang dilakukan dengan menggambarkan dan menjelaskan Sistem Pemerintahan Islam Study Tentang Implementasi Kebijakan Pemerintah terhadap Perda Baca Tulis Al-Quran di Kota Makassar.

Penelitiaan ini menggunakan fokus penelitian yaitu Kantor Balai Kota Makassar, Kantor DPRD, Kantor Kementerian Agama Kota Makassar dan Salah satu Organisasi Kepemudaan serta beberapa perwakilan dari masyarakat yang berada dalam wilayah Kota Makassar. Dengan demikian, memulai penelitian ini jumlah responden yang akan dijaring adalah sebanyak 50 orang yang diharapkan akan menggambarkan atau mewakili pendapat terhadap Sistem Pemerintahan Islam Study Tentang Implementasi Kebijakan Pemerintah terhadap Perda Baca Tulis Al-Quran di Kota Makassar.

Penelitian ini akan dianalisa secara deskriptif yakni hasil dari wawacara dengan informan dan responden yang juga akan didukung dengan data-data kuantitatif dalam bentuk tabulasi frekuensi untuk mendapatkan penggambaran mengenai Sistem Pemerintahan Islam Study Tentang Implementasi Kebijakan Pemerintah terhadap PERDA Baca Tulis Al-Quran di Kota Makassar, kami mengambil sumber data penelitian ini meliputi Kabag Hukum dan Kesra, Ketua-Ketua Komisi DPRD, Ka. Kapontren Kementerian Agama 
Kota Makassar, BKPRMI dan beberapa orang perwakilan dari masyarakat Kota Makassar.

\section{HASIL DAN PEMBAHASAN}

\section{Hasil}

Kebijakan dan langkah-langkah yang diambil pemerintah dalam penerapan perda.

Pengusul pembuat Perda Baca Tulis AlQuran (DPRD Kota Makassar) Dalam pembahasan Perda Baca Tulis Al-Quran, DPRD berperan aktif dalam pembuatan PERDA BCTA yang murni inisiatif dari pada DPRD itu sendiri yang dimana diutarakan langsung oleh Pak Mudzakkir Ali dalam pertemuan di Gedung DPRD pada Tanggal 12 November 2012 pukul 14:45 Wita.

DPRD berinisiatif dalam pembuatan Perda BCTA dengan melihat kondisi di masyarakat yang dimana yang fasih dalam membaca AlQuran hanya berkisar antara 25\% saja dari jumlah masyarakat kota Makassar, sehingga melihat hal ini DPRD berinisiatif untuk membuatkan suatu aturan dalam bentuk perda yang dimana perpanjangan dari peraturan daerah Provinsi Sulawesi Selatan No.04 tahun 2006 tentang bebas buta aksara yang dibuat oleh Pemprov. DPRD lebih memperinci lagi tentang hal tersebut yang dimana dalam Perda memiliki dua bahwa pendidikan baca tulis Al-Qur'an merupakan bagian dari aktifitas hidup masyarakat muslim di Kota Makassar, maka dipandang perlu adanya upaya yang intensif dan berkesinambungan dengan melakukan standarisasi lilsensi bagi para pengajar pendidikan baca-tulis AlQur'an.

DPRD berinisiatif dalam pembuatan Perda BCTA dengan melihat kondisi di masyarakat yang dimana yang fasih dalam membaca AlQuran hanya berkisar antara 25\% saja dari jumlah masyarakat kota Makassar, sehingga melihat hal ini DPRD berinisiatif untuk membuatkan suatu aturan dalam bentuk perda yang dimana perpanjangan dari peraturan daerah Provinsi Sulawesi Selatan No.04 tahun 2006 tentang bebas buta aksara yang dibuat oleh Pemprov. DPRD lebih memperinci lagi tentang hal tersebut yang dimana dalam
Perda memiliki dua bahwa pendidikan baca tulis Al-Qur'an merupakan bagian dari aktifitas hidup masyarakat muslim di Kota Makassar, maka dipandang perlu adanya upaya yang intensif dan berkesinambungan dengan melakukan standarisasi lilsensi bagi para pengajar pendidikan baca-tulis Al-Qur'an.

Sasaran pendidikan baca-tulis Al-Qur'an adalah peserta didik yang beragama islam pada semua jalur dan jenjang pendidikan, Setiap Murid SD Siswa SLTP dan Siswa SLTA yang akan menamatkan jenjang pendidikan wajib pandai Baca Tulis Al-Qur'an melalui intra kurikuler sesuai dengan tingkat pendidikannya.

DPRD berfungsi sebagai penggagas utama lahirnya Perda Baca Tulis Al-Quran yang sadar dan prihatin akan kondisi generasi penerus bangsa yang tidak pandai dalam Baca Tulis Al-Quran khususnya Ummat Islam, diharapkan generasi yang mengerti tentang Baca Tulis Al-Quran semakin meningkat bahkan seluruh Umat Islam khususnya di Kota Makassar akan paham dan tau betul tentang Baca Tulis Al-Quran yang beriman dan bertaqwa kepada Allah yang Maha Esa.

Pengambil kebijakan (Pemerintah Kota) Esensinya terletak bagaimana sebuah lembaga pendidikan betul-betul memiliki kepedulian kepada anak didik untuk pandai dalam baca tulis Al-Quran dan siswa tidak akan pernah maju-maju apabila si-Pendidik menyerahkan penuh tanggung jawab kepada orang tua anak tidak bersama-sama dalam mendidik anak sebagai generasi penerus bangsa yang paham akan baca tulis Al-Quran.

Bagi anak yang beragama islam yang bersekolah di sekolah non-muslim maka akan diberikan/difasilitasi dalam pelajaran agamanya begitupun sebaliknya, serta disekolahsekolah umum lainnya. Penerapan perda baca tulis Al-Quran mendorong agar sekolahsekolah dapat memberikan sarana dan prasarana yang dibutuhkan dalam mengajar anak menjadi generasi qurani yang teruraikan pada tabel 1 (satu)-10 (sepuluh)

Jadi posisi pemerintah dalam Perda berperan aktif dalam memberikan fasilitas baik sarana maupun prasarana demi kelancaran Perda BCTA, baik pemberian izin bagi 
lembaga pendidikan dalam pengelolaannya maupun memberikan Insentif kepada para pendidik dalam pelaksanaan pemberian pendidikan kepada generasi penerus dalam proses Belajar Baca Tulis Al-Quran.

Tanggapan salah satu instansi pemerintahan (Kementerian Agama Kota Makassar) dan salah satu Ormas masyarakat (BKPRMI Kota Makassar) serta beberapa perwakilan dari Masyarakat dalam pemberlakuan perda.

Kementerian Agama Kota Makassar adalah Kementerian Agama melaksanakan/ mendidik sudah sejak lama pelaksanaan baca tulis Al-Quran karena merupakan tugas dari pada Kementerian Agama dalam mendidik generasi penerus dalam belajar memahami AlQuran, apalagi dengan dikeluarkannya PERDA Provinsi Sulawesi Selatan No.04 Tahun 2006 inilah yang menjadi landasan Kementerian Agama dalam membina anak didik agar paham akan baca tulis Al-Quran. Sebagai pemberi sertifikat kepada santri yang telah dinyatakan lulus seleksi/ujian yang diuji oleh Kementerian Agama yang sumber dananya dari masyarakat sebagai penggati biaya administrasi. Lembaga yang mengelola selain Kementerian Agama ada Lembaga Kepemudaan yang juga mengelolah hal tersebut yaitu BKPRMI, dalam hal ini Kementerian Agama menambahkan bahwa disini dalam pendidikan ini Kementerian Agama bertindak sebagai Negerinya sedangkan BKPRMI sebagai swastanya apabila termasuk dalam pendidikan Formal.

Kementerian Agama selalu mengadakan pendataan terlebih dahulu terhadap Lembaga yang melakukan pendidikan terhadap pembinaan Baca Tulis Al-Quran kepada MasjidMasjid, Mushollah maupun Pengajian Kampung. Dengan disahkannya PERDA Baca Tulis Al-Quran membuat masyarakat sadar akan pentingnya memahami Baca Tulis Al-Quran hingga tidak ada lagi umat Islam yang tidak tahu lagi tentang Al-Quran sehingga tercipta Masyarakat Qurani yang beriman dan bertaqwa, yang sebagaimana di gambarkan pada tabel 1-10.

BKPRMI Kota Makassar merupakan suatu Lembaga Kepemudaan yang mengurus tentang Taman Kanak-Kanak Al-Quran yang tugasnya mendidik agar anak-anak mengerti dan tahu baca tulis Al-Quran. BKPRMI singkatan dari Badan Komunikasi Pemuda Remaja Mesjid Indonesia, yang memiliki arah dan tujuan menjadikan generasi remaja yang pandai membaca dan memahami Al-Quran.

Dengan diperdakannya Baca Tulis AlQuran BKPRMI terasa lebih diperhatikan dengan Pemerintah setempat, karena dengan diberlakukannya perda tersebut mejadikan BKPRMI memiliki legalitas, hingga dalam mendidik anak-anak dan remaja sehingga BKPRMI merasa diperhatikan dan diberi peluang dang tanggung jawab oleh Pemerintah.

Sudah jelas dengan berlakunya PERDA Baca Tulis Al-Quran memberikan peluang kepada Lembaga untuk dapat memberikan sumbangsih kepda generasi penerus bangsa menjadi generasi Qurani yang berakhlah dan berbudi pekerti yang baik serta dapat dipercaya. Secara terpisah kami meberikan angket dengan rincian dan mendapatkan hasil yang terurai dalam tabel 1 (satu)-10 (sepuluh).

\section{Pembahasan}

Dalam penelitian ini hasil yang dicapai sangat maksimal karena mulai dari pemerintah, DPRD Kota Makassar, Kementerian Agama, BKPRMI dan Masyarakat sangat antusias sekali dengan diberlakukannya PERDA Baca Tulis Al-Quran yang sebagaimana tergambar dalam Tabel Frekuensi yang terurai dari pertanyaan sebagai berikut:

Tabel 1. Pemahaman Tentang PERDA Baca Tulis Al-Quran

\begin{tabular}{|c|l|c|c|}
\hline No. & \multicolumn{1}{|c|}{ Kategori Jawaban } & F & Persen \% \\
\hline 1. & Sangat setuju & 9 & 18 \\
\hline 2. & Setuju & 38 & 76 \\
\hline 3. & Kurang setuju & 3 & 6 \\
\hline 4. & Tidak setuju & - & - \\
\hline 5. & Sangat tidak setuju & - & - \\
\hline & Jumlah & 50 & 100 \\
\hline
\end{tabular}

Sumber: hasil olah kosioner, November 2012 
Dari hasil yang dicapai dalam tabel diatas tergambar ada beberapa orang dari kosioner yang belum tahu betul tentang baca tulis AlQuran, pemerintah harus lebih intensif lagi dalam hal ini.

Diharapkan dengan bantuan media, pemerintah lebih dapat membagi informasi kepada masyarakat hingga hubungan emosional tetap terjaga. disini peran media juga sangat diperlukan untuk menyampaikan sebuah peraturan yang telah maupun yang akan dibuat pemerintah hingga masyarakat luas dapat mengetahui tentang peraturan Daerah (PERDA) tersebut dan juga diharapkan bagi masyarakat maupun aparatur pemerintahan yang telah mengetahui aturan tersebut dapat di publikasikan.

Tabel 2.

Pemahaman tentang aturan yang diberlakukan pemerintah

\begin{tabular}{|c|l|c|c|}
\hline No. & Kategori Jawaban & F & Persen \% \\
\hline 1. & Sangat setuju & 7 & 14 \\
\hline 2. & Setuju & 38 & 76 \\
\hline 3. & Kurang setuju & 5 & 10 \\
\hline 4. & Tidak setuju & - & - \\
\hline 5. & Sangat tidak setuju & - & - \\
\hline & Jumlah & $\mathbf{5 0}$ & $\mathbf{1 0 0}$ \\
\hline
\end{tabular}

Sumber: hasil olah kosioner, November 2012

Dari hasil penelitian dapat terlihat dari tabel diatas masih ada beberapa orang yang kurang paham akan aturan yang diberlakukan oleh pemerintah tetapi masih ada masyarakat yang masih belum paham tentang PERDA Baca Tulis Al-Quran karena pemerintah menyampaikan atau mempublikasikan suatu aturan belum maksimal hingga masyarakat ada yang sudah mengetahui ada juga yang belum mengetahui hal tersebut.

\begin{tabular}{|c|l|c|c|}
\hline No. & Kategori Jawaban & F & Persen \% \\
\hline 1. & Sangat setuju & 17 & 34 \\
\hline 2. & Setuju & 23 & 46 \\
\hline 3. & Kurang setuju & 10 & 20 \\
\hline 4. & Tidak setuju & - & - \\
\hline 5. & Sangat tidak setuju & - & - \\
\hline & Jumlah & 50 & 100 \\
\hline
\end{tabular}

Sumber: hasil olah kosioner, November 2012

Dari hasil penelitian yang digambarkan dalam tabel tersebut, masih kurangnya mansyarakat yang tahu tentang Baca Tulis AlQuran. Masyarakat berharap pemerintah menyebarluaskan aturan tersebut.

Disini bukan hanya Pemerintah berperan tetapi juga media sangat diperlukan baik media cetak maupun media elektronik, hingga perda tersebut dapat diketahui oleh halayak ramai khususnya Masyarakat Kota Makassar. Jadi, selain Pemerintah, Masyarakat dan lembaga pendidikan yang berperan dalam hal ini tetapi juga media juga sangat berperan untuk menyampaikan PERDA tersebut.

Tabel 4

Pemerintah memberikan sarana-prasarana pada lembaga pendidikan demi pelaksanaan dan pemberlakuan PERDA Baca Tulis AI-Quran.

\begin{tabular}{|c|l|c|c|}
\hline No. & Kategori Jawaban & F & Persen \% \\
\hline 1. & Sangat setuju & 21 & 42 \\
\hline 2. & Setuju & 15 & 30 \\
\hline 3. & Kurang setuju & 14 & 28 \\
\hline 4. & Tidak setuju & - & - \\
\hline 5. & Sangat tidak setuju & - & - \\
\hline & Jumlah & $\mathbf{5 0}$ & $\mathbf{1 0 0}$ \\
\hline
\end{tabular}

Sumber: hasil olah kosioner, November 2012

Dari tabel diatas tersebut tergambar, masih kurangnya lembaga pendidikan yang 
mendapatkan santunan/bantuan baik berupa sarana maupun prasarana. Diharapkan pemerintah turun langsung melihat kondisi yang terjadi di masyarakat dan memberikan bantuan baik sarana maupun prasarana.

Masyarakat berharap pemerintah memberikan sarana prasarana bagi lembaga pendidikan yang membutuhkan bantuan, hingga apa yang dicita-citakan akan terlaksana secara maksimal. Dengan diberikannya bantuan tersebut Pemerintah dapat mementau jalannya Lembaga tersebut yang sewaktu-waktu pemerintah dapat memberikan sanksi kepada lembaga pendidikan apabila sarana-prasarana telah terpenuhi.

Tabel 5. Kesadaran Masyarakat akan perlunya memahami Al-Quran melalui belajar Baca Tulis Al-Quran

\begin{tabular}{|c|l|c|c|}
\hline No. & Kategori Jawaban & F & Persen \% \\
\hline 1. & Sangat setuju & 18 & 36 \\
\hline 2. & Setuju & 28 & 56 \\
\hline 3. & Kurang setuju & - & - \\
\hline 4. & Tidak setuju & 4 & 8 \\
\hline 5. & Sangat tidak setuju & - & - \\
\hline & Jumlah & 50 & 100 \\
\hline
\end{tabular}

Sumber: hasil olah kosioner, November 2012

Dalam hasil tabel diatas menggambarkan mesih adanya masyarakat yang kurang sadar (paham) betapa pentingnya Baca Tulis AlQuran demi terciptanya masyarakat yang fasih baca tulis Al-Quran. Dengan pahamnya masyarakat paham Baca Tulis Al-Quran membuat generasi penerus menjadi lebih baik hingga generasi penerus kita menjadi terarah dan perkelahian maupun tawuran yang terjadi dimana-mana bisa diminimalisir dengan adanya PERDA ini masyarakat selalu merasa diawasi dalam menjadi kehidupan sehari-harinya.

Dengan diberlakukannya PERDA Baca Tulis Al-Quran tersebut pemerintah lebih memperhatikan kitab suci yang diyakininya dengan tidak mengganggu ummat agama lain dan memperlihatkan bahwa inilah agama Islam yang penuh dengan Rahmatan lil'alamin (rahmat bagi seluruh alam). Hingga dalam bermasyarakat dapat terjalin hubungan yang harmonis tanpa harus saling mengganggu ummat lain.

\section{KESIMPULAN}

Sistem Pemerintahan (politik) Islam sangat jauh berbeda dengan Sistem Politik, ideologi-ideologi dan isme-isme akal manusia. Islam memiliki tafsiran dan bentuk yang khusus dan istimewa tentang pemerintahan.

Sistem Pemerintahan Islam adalah Sistem Pemerintahan yang menggunakan Al Quran dan Sunnah sebagai rujukan dalam semua aspek hidup, seperti dasar undang-undang, Mahkamah Perundangan, Pendidikan, Dakwah dan Perhubungan, Kebajikan, Ekonomi, Sosial, Kebudayaan dan Penulisan, Kesehatan, Pertanian, Sains dan Teknologi, Penerangan dan Peternakan.

Istilah Sistem Pemerintahan berasal dari gabungan dua kata Sistem dan Pemerintahan. Kata Sistem merupakan terjemahan dari kata sistem (bahasa Inggris) yang berarti susunan, tatanan, jaringan, atau cara.

Dengan berlakunya Perda Baca Tulis AlQuran memberikan spirit baru yang dapat menjadikan generasi yang panda membaca dan menulis Al-Quran serta memahaminya yang dimana hasil penelitian akhir yang menyatakan setuju sebanyak 18 orang yang menyatakan kurang setuju sebanya 2 orang tetapi pada intinya Perda Baca Tulis Al-Quran sangat diterimah dalam masyarakat pada umumnya.

Dengan berlakunya Perda Baca Tulis AlQuran generasi kita kedepannya bukan hanya paham dengan pendidikan umum tetapi juga menjadi generasi Qurani yang nantinya generasi kita akan menjadi kokoh dengan hantaman dari luar hingga masyarakat Indonesia menjadi berbobot khususnya generasi penerus Kota Makassar yang akan membuka jendela dunia bahwa inilah bangsaku tercinta.

DAFTAR PUSTAKA 


\section{DAFTAR PUSTAKA}

Ahmad Jaiz, Hartono, H, 1999, “Dibawah Bayang - bayang Soekarno-Soeharto: Tragedi Politik Islam Indonesia dari Orde Lama hingga Orde Baru". Darul Falah Islam Kaffa, Jakarta.

Arvio, Idham, 2012, "Pengertian Implementasi Kebijakan", http:://localhost/G:/ bahan/pengertian-implementasikebijakan.html, Oktober 2012 14:50

Bin Abdurrahman Ali Bassam, Abdullah, 2008, "Syarah Hadits Pilihan Bukhari Muslim (Taisirul-Allam Syarh Umdatul Ahkam)", Darul Falah (Buku Islam Kaffah), Jakarta.

Bukhreissy, Husain, "Himpunan Hadits Pilihan Hadits Shahi Bukhari", Al Ikhlas, Surabaya.

Departemen Agama Republik Indonesia, 2005, Al-Qur'an dan terjemahannya,
Yayasan Penyelenggaraan Penterjemah/ Penafsiran Al-Qur'an, Jakarta.

Gieyono, Muhammad dkk, 2010, "Struktur Pemerintahan Dalam Islam", http:// ahmadnaufa.wordpress.com/2010/ 04/18/struktur-pemerintahan-dalamislam/, Oktober 2012 10:02.

Kasim, Nur, 2010, "Sejarah kota Makassar Sejarah dan Perkembangan Pemerintahan kota Makassar", http:// nurkasim49. blogspot.com/, Oktober 2012 14:15.

Megawati, Lena, 2012, "Sistem Pemerintahan Demokrasi Indonesia", http:// lenamegawati.blogspot.com/2012/ $01 /$ normal- 0 -false-false-false-in-xnone-x.html, Oktober 2012 09:50.

Mohammad, Arshad, 2010, "Sistem Pemerintahan Islam Suatu Sinar Keadilan", http://members.tripod.com/ ibn_muhammad/sistem.html, 